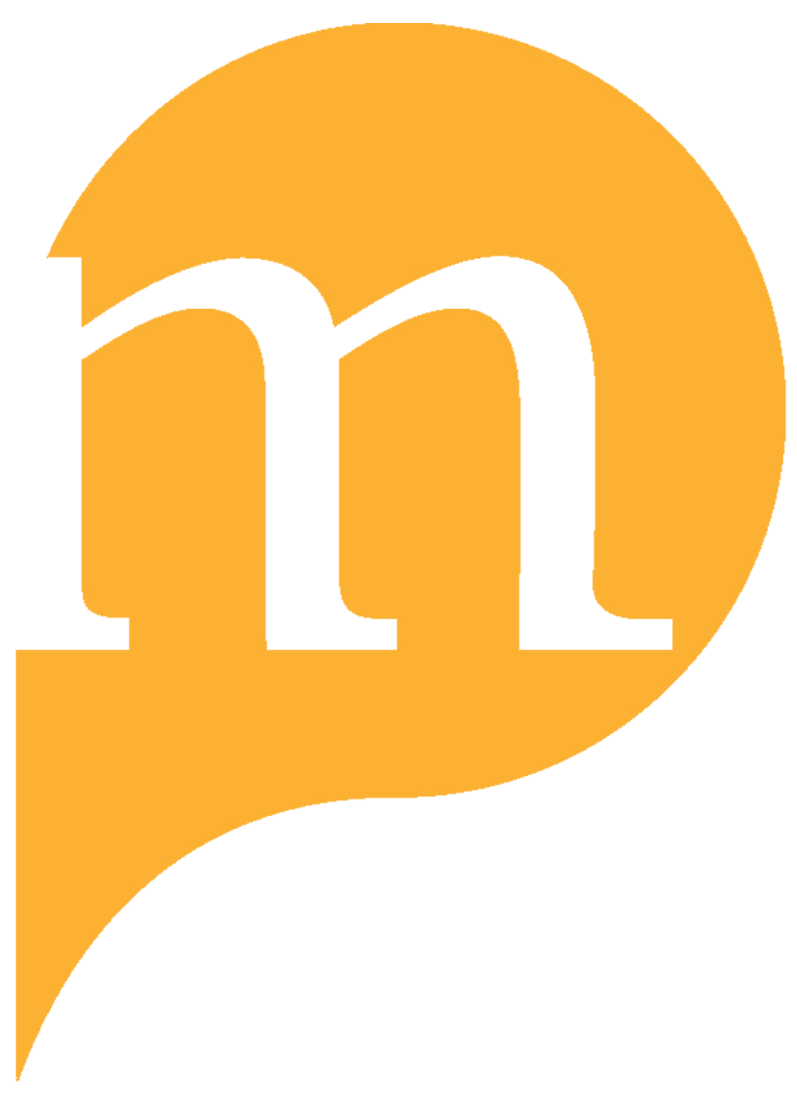

PROJECT MUSE 


\title{
"Who Does What to Whom and How": "Knowing Children" and Depictions of Prostitution in Anglophone Young Adult Literature
}

\author{
Lydia Kokkola, Elina Valovirta, and Janne Korkka
}

\begin{abstract}
A lthough depictions of sexually active adolescents have been de rigueur in fiction for teenage readers from the early 1970s, Kimberley Reynolds has argued that since the mid-1990s "attitudes to and writing about sex, sexuality and relationships between the sexes [are] one of the most radically changed areas in contemporary children's literature" (114-15). The "radical" change outlined by Reynolds is a dramatic transition from coercive didacticism to "inyour-face prose" (122). As a result, she claims, twenty-first-century fiction for teens sides with the adolescent in order to communicate the view that behavior previously deemed taboo will be tolerated, if not celebrated. This is partly because Reynolds, like us, primarily discusses Anglophone texts. In Sweden and Swedish-speaking Finland, for instance, the so-called sexual revolution of the 1960s found its way into teenage fiction more forcefully in the ' 70 s and ' 80 s than it did in the more puritanical Anglophone world. As a result, the changes Reynolds identifies as taking place in the third millennium in Anglophone fiction for teens happened earlier in Sweden, and contemporary Swedish teenage fiction assumes readers are more liberated, even though it still expects children and teenagers to be heterosexual. ${ }^{1}$ Somewhat curiously, Reynolds also observes that those seeking to find out "who does what to whom and how" (117) will receive less explicit information than did their counterparts in the 1970 s - a finding also supported by the larger study from which this article is drawn (see Kokkola, Fictions). ${ }^{2}$
\end{abstract}

Lydia Kokkola is Professor of English and Didactics at Luleå University of Technology, Sweden. Her monograph on adolescent sexualities, Fictions of Adolescent Carnality, will be published by John Benjamins in 2013.

Elina Valovirta is Post-Doctoral Researcher employed by thr Turku Institute for Advanced Studies (TIAS) at the University of Turku, Findland. Her forthcoming monograph on affective feminist reader theory and sexuality in Caribbean women's writing will be published by Rodopi.

Janne Korkka is Lecturer in English at the University of Turku, Findland. His monograph on representing alterity in the work of the Canadian author Rudy Wiebe will be published by Rodopi in 2013 .

(c) 2013 Children's Literature Association. Pp. 66-83. 
This lack of detail is no doubt partly due to still-existing taboos against producing overtly erotic fiction for the young. We propose that this lack of detail signals that the contemporary authors we discuss do expect that their presumed mid-teen readers know about the mechanics of sexual acts- "who does what to whom and how" (Reynolds 117). They are what Anne Higonnet terms "Knowing children" (12), who are perceived as knowing about sexual desire. Piecing Reynolds's and Higonnet's ideas together, we claim that treating teenagers as knowing children has resulted in adolescent readers who think that they know a great deal about sex. In the four Anglophone narratives we discuss below, the sex industry is used as a topic to confront such "knowing" readers with information that challenges them to reassess what they really do know about sex, and perhaps recognize that they know less than they think they do. ${ }^{3}$ Furthermore, these texts' positioning of the reader as a knowing child results in a didactic slant, which we shall uncover. All four narratives invite their readers to draw connections between sexuality and violence, and the potential for sex to rob an individual of her autonomy. Although these connections are drawn within the context of the prostitution, we argue that the narratives' focus on combining sex with violence is part of a larger discourse of discouraging adolescents from becoming sexually active, as the focus is more on the sexual aspects of prostitution than the financial ones. For all the shock value of their surface story lines, these narratives ultimately express fairly conservative attitudes.

The sex industry has made its presence felt in children's literature before. In her discussion of "Street Arabs" in Victorian stories for children, Elizabeth Thiel identifies numerous hints that the poor may be forced to turn to prostitution in stories for children published in the late nineteenth century (43-71); however, none of the books she discusses depicts the everyday life of such prostitutes. The twentieth century saw significant improvements in the living standards of the general population, and changes in the legality of the sex industry certainly reduced the visibility of prostitution, and quite probably the actual numbers (Ringdal). The teenage prostitute, a common enough figure on the late nineteenth-century streets, would not appear as a character in her own right in books for readers of her own age until the start of the twenty-first century. The number of works on this topic is, unsurprisingly, low. Some, like Paige Dearth's Believe Like a Child (2011), are quasi-autobiographical, but those we will discuss here are ostensibly written by politically active authors to entertain teenage readers as well as educate them.

The four contemporary Anglophone writers we discuss-Melvin Burgess, Judy Waite, Patricia McCormick, and Mary Hooper—present the sex industry as a perfectly normal topic for adult-adolescent discussion. Their matter-offact acknowledgement that some teenagers do support themselves and/or their families, pimps, or drug habits by selling their bodies situates their adolescent readers as equals who, like the authors, know that sex can be bought and sold. This appearance of equality is then challenged as they are confronted with the darker aspects of prostitution, typically in the form of rape and other physical 
violence, in ways which suggest that the readers did not understand more than the mechanics of this transaction. All four writers instruct their young audience on the emotional impact sex may have, and use shock tactics to drive home the message that their readers know less than they think they do.

Given the novelty of prostitute protagonists in teenage fiction, it is not surprising that the few writers who dare to create such characters are politically committed individuals who encourage their young readers to be aware of the wider social issues surrounding the sex industry; they seem especially concerned with the conditions that lead to teenage prostitution. The texts do not overtly preach at their audience; on the contrary, much of their appeal relies on their ability to treat young readers as though they were not moralizing (Rudd; Kokkola, "Metamorphosis"). But if we scratch the surface, we find that these texts are keen to curb the libidos of adolescents who might wish to emulate sex workers.

We divide the four narratives into two types: those that depict prostitutes as the victims of poverty, and those portraying prostitution as a choice. This is in line with the two basic feminist views of prostitution visible in public discourses in which it is seen as either exploitation or a form of chosen labor, when in fact the topic is far more complex (Sanders, O'Neill, and Pitcher 5). In her now seminal The Idea of Prostitution, Susan Jeffries describes the separation of forced and voluntary prostitution as a "false distinction" (10). For Jeffries and others like her, prostitution is "the choice made by those who have no choice" (Wisterich, qtd. in Farley 110; emphasis original). As we shall show, the authors of these narratives also deconstruct the notion of free choice, and this is part of the knowledge they wish to impart to young readers. Indeed, all four narratives can even be read as didactic counterclaims to the notion of voluntary prostitution, as the texts warn readers that they cannot maintain their autonomy once they enter the sex industry.

Narratives about forced prostitution include Sold (2008) by Patricia McCormick, a novel based on the author's years as an investigative reporter on the Indian subcontinent. Endorsed by Amnesty International for "contributing to a better understanding of human rights and the values that underpin them" (back cover), the novel traces the story of Lakshmi, a Nepalese girl who is sold into sexual slavery in India by her stepfather. "Charlotte," a short story by Mary Hooper set in Victorian London, appears in the anthology Losing It (2010), a collection of stories about having sex for the first time. The blurb claims that the collection offers "Everything you ever wanted to know about virginity but your parents were too embarrassed to tell you." Rape and prostitution in the Victorian era are unlikely to be the topics the "knowing" readers of this collection were expecting; they may well have come to the text in search of sexual titillation. If they have, the brutality of Charlotte's fate is an admonishment. The story depicts the fifteen-year-old protagonist's decision to sell her virginity and begin working as a prostitute in order to support herself and her younger brothers after their mother's death. Written and marketed for English-speaking 
teenagers in the wealthier parts of the world, Sold and "Charlotte" both depict prostitution as something that happens to other people, in another place (Nepal) or another time (the nineteenth century). By distancing readers from the protagonists' experiences, the narratives offer reassurance that "this will not happen to you." Despite this protective gesture, readers of these two narratives are expected to learn about the abuse of others. They are also encouraged to pity Lakshmi and Charlotte, to understand how they were forced into prostitution by poverty, and to blame those who took advantage of their plight.

Novels that depict prostitution as a choice include Judy Waite's Game Girls (2007) and Melvin Burgess's Junk (1996; published as Smack in North America the same year). Both novels feature white, middle-class girls who become prostitutes simply because they consider it to be an easy way to earn money. Both novels rely on multiple focalization-each chapter is focalized through a different character - in order to allow insight into the attitudes and motivations that lead the girls to decide that working in the sex industry is an acceptable option. While on the surface both novels present prostitution as a choice, on closer examination both reveal that the time frame for "choice" is quite limited before the girls are disempowered by the workings of the industry. Both novels assume their teenage readers know a fair bit about prostitution, but both are keen to describe its damage to the girls' bodily and mental integrity. In other words, both novels assume their predominantly middle-class readers know that sex can be bought and sold, but do not know how dangerous, emotionally and physically, prostitution can be for the individual. ${ }^{4}$ They also encourage readers to realize how much they do not know, which includes a rejection of the idea of an autonomous sex worker. By disguising their didacticism and seeming to side with the teenage protagonists, Burgess and Waite can reinforce their didactic message to readers who would reject an overtly moralizing lecture.

Sexual innocence, often simplified as a lack of sexual knowledge, is widely acknowledged to be the sine qua non attribute of an idealized childhood. ${ }^{5}$ Nevertheless, third-millennium teenagers are expected to know a good deal about sex, and to be able to make sensible choices and decisions, such as using contraceptives or abstaining (Levine; Emge; Duncan). Focusing on the information gaps in the four representative texts, we argue that the narratives reveal assumptions about their readers' sexual knowledge. We then consider what new information about prostitution the narratives deem appropriate and/ or necessary for their young readers to know, locating this discussion within ongoing debates about didacticism and sexual repression in teenage literature.

\section{Victims of Vice: Forced Prostitution and the Loss of Innocence}

In an examination of the similarities in discourse surrounding the depiction of white slavery and sex trafficking, Jo Doezema identifies a number of recurring motifs which are also present in McCormick's and Hooper's representations of forced prostitution in Sold and "Charlotte": these motifs include "innocence; 
youth and virginity; deception and violence" (31). Doezema delineates ways in which the general public distinguishes between the "'innocent,' unwilling victim" and "'bad' women, i.e., prostitutes" (24). McCormick and Hooper assume that their teenage readers will make similar distinctions, and their texts offer an idealized image of the victim. Lakshmi is a young girl who loves her mother dearly and works hard to supplement their income. Charlotte is equally industrious, but less efficient. Her sewing skills are simply not good enough to support the family after her mother has died. The child forced into prostitution, as Jacqueline Rose observes in her commentary on the "discovery" of child prostitution in Victorian media, is "at once (and this is the key) totally sexualised and totally innocent" (99). It is her quality of innocence that distinguishes her from the so-called bad women who supposedly choose to become prostitutes of their own volition. Doezema notes that girls destined for prostitution are typically depicted as naive young virgins, usually from the country (24-28). We find this dualistic pattern in McCormick's and Hooper's texts as well.

The cover of McCormick's Sold exaggerates Lakshmi's youth by depicting a girl much younger (perhaps age nine) than the protagonist's thirteen years. The full-frontal gaze of a prepubescent, Nepalese girl, wearing a rough shawl, stares out at the reader. Her mouth is covered, hiding her expression and perhaps indicating her lack of voice. Her eyes look upward, appealing to the reader, but do not indicate that anything is awry. The novel opens in a Nepalese village, where Lakshmi and her mother tend their crops and attempt to earn money to buy a new tin roof. Despite the family's poverty, the cruelty of Lakshmi's drunken stepfather, and the difficulties of their daily lives, the early part of the novel also celebrates mother-daughter relationships and the women's intimate connection with the soil and its growing plants.

The novel presents Lakshmi's life as a series of vignettes, which she narrates in the present tense: a formal feature that situates her as knowing only her present and her past. She is unable to anticipate her future, but readers are encouraged to do so. The long description of Lakshmi's journey from her village home in the Nepalese Himalayas across the border into an unnamed Indian city (presumably Kolkata) reveals her ignorance and implied innocence. Lakshmi has never tasted Coca-Cola, does not know that there is more than one city in the world, and has never traveled by bus or train. Since these are things that readers are likely to know about, they are encouraged to feel more knowledgeable than the protagonist-narrator. At the same time, McCormick introduces information about sex trafficking, but how quickly readers understand what is happening will depend on what they already know. For instance, in the scene in which Lakshmi's stepfather sells her to a trader for 400 rupees (about $4 €$ or \$6 US), the "new auntie, who smells of amber and jasmine and possibility" (50), has factored Lakshmi's lack of hips and plain facial features into the price paid. Lakshmi comments, "I don't understand at all. A great deal of money has just been paid for work I have not yet done" (60). Knowing readers will recognize that Lakshmi will not be going to work as a maid as she 
assumes, but precisely how much they understand about what is happening will depend on what they already know. If they know nothing about sex trafficking, they will not be positioned to feel ignorant, as they will learn alongside Lakshmi. In this way, the novel is overtly didactic, but never confrontational; the young reader is never made to feel foolish for not knowing about girls in Lakshmi's situation.

Mary Hooper's Charlotte is neither as naive nor as young as Lakshmi, nor is she a country innocent. Charlotte knows what she is doing when she sells her virginity, but this historical narrative is designed to reveal how even girls who supposedly know what they are doing can also be innocent victims. When Charlotte's mother dies, there is not even enough money available to pay for a pauper's funeral. At fifteen, Charlotte is left to fend for herself and her two younger brothers. At first, she assumes she will be able to earn money sewing shirts at home as her mother did, but quickly realizes that she lacks the skill. The acute poverty of the family signals to the more observant reader that since the mother could not feed her children with Charlotte's assistance, it is unlikely that Charlotte will manage alone.

Charlotte goes to visit her mother's employer, Tommo. During her walk, she is "horribly fascinated" by the prostitutes around Piccadilly, but is horrified when Tommo suggests that she take up the same profession. Nevertheless, at the end of their meeting, she agrees to give him a kiss in return for a shilling (127). Toward the end of the story, she accepts that she must take up prostitution for at least a few weeks in order to pay for a doctor to treat her youngest brother. But when she asks Tommo for short-term help in procuring clients, he declares, "If I set you up in a place with a decent gown or two, then I own you. Until such time as I decide you're past your best, that is" (143). He also insists that she will start by repaying the six shillings she owes for shirt materials, then rips off the blanket she is using as a shawl. The narrative ends without describing Charlotte's rape or her life as a prostitute, just the wave of nausea she experiences as she realizes that "as the blanket fell from her shoulders, it seemed that all her future hopes and dreams fell away with it" (143). The reader is supposed to be knowledgeable enough to understand what will happen, and sympathetic enough to understand that poverty has left Charlotte with no alternative.

Charlotte's story is set in the Victorian era, when the only social welfare available comes from the mutual support of the poor neighbors and orphanages; she has nowhere else to turn to for help. Readers of the story can be assumed to know that such help is available today, but are nevertheless encouraged to see how prostitution can be regarded as "the choice made by those who have no choice" (Wisterich in Farley 110; emphasis original).

Like Hooper, McCormick encourages readers to understand that poverty can drive an individual into becoming a prostitute. In the Indian brothel, Lakshmi discovers that several of the women working there have been compelled to do so by social circumstance. Pushpa, a woman suffering from lung disease, came 
to the brothel to work when her husband died and she could find no other way to support her two young children. Shilpa became a prostitute because her mother was one: "It is the family trade" (173). Monica returns to the brothel because she has been disowned by her family and does not wish to bring shame on her son. These women's stories introduce young Western readers to the ways in which poverty, social indifference, and misogyny can leave women without other choices. All these women are presented as victims, and their victimhood is central to the pity that McCormick seeks from her young readers.

The foregrounded victimhood of the women in these two texts undermines the possibility that they could find agency through their work. Even though Charlotte sees the other prostitutes acting in ways that imply a significant degree of autonomy, she is presented as an innocent whom Tommo can exploit. Sold also contains independent female characters within the sex industry, such as the "auntie" who purchases Lakshmi, but such characters remain, in E. M. Forster's terms, flat; the round characters of McCormick's novel are all victims. By maintaining the binarism of the innocent victim versus the bad woman, both narratives position the reader as an empathetic individual who will align herself with the victims. More specifically, readers are encouraged to align themselves as innocents: Lakshmi is shocked by her fate, and readers are positioned to be stunned alongside her; Charlotte knows what prostitutes do, and readers are aligned to fill in the gap and understand that she is raped by Tommo. They, too, are expected to know the mechanics of the trade, but not what might cause an individual to sell her body or the violence this entails.

Although McCormick and Hooper seem aware that their readership includes sexually active teenagers, their narratives valorize lack of sexual knowledge: the "knowing" characters are "bad" women. All the sexual encounters we see are characterized by violence and lack of volition. This is hardly surprising in narratives depicting girls driven into prostitution by poverty and social circumstance. Although this makes sense in terms of the plot, this focus on traumatic sex adheres to the pattern of repressing adolescent interest in sexual matters outlined in Roberta Seelinger Trites's Disturbing the Universe (2000). According to Trites, adolescents who become sexually active are perceived as encroaching on adult territory; as a result, they are typically punished by pregnancy, diseases, damaging relationships, violence, or even death (84-116). Although it is a highly distasteful formulation to refer to Lakshmi and Charlotte as "sexually active," it is noteworthy that they are also punished in the ways Trites identifies. Since neither girl benefits economically, the focus of both narratives is on the sexual aspects of prostitution. So although the girls are depicted as innocents, these texts also conform to the pattern Trites establishes, encouraging readers to connect sex with violence and distress.

Summing up, the stories by McCormick and Hooper feed the idea that one should distinguish between the innocent victims of the sex industry and the "bad" women Doezema identifies by their constant focus on their protagonists' pathos. By focusing on poverty as a cause of prostitution, the texts imply that 
not all prostitutes are worthy of the same degree of pity. In the novels Junk and Game Girls, Melvin Burgess and Judy Waite abandon the innocent victim trope and attempt to provide credible explanations of why girls from seemingly desirable homes might make choices that result in their working in the sex industry. These are not choices made by people who have no choice, but seemingly empowered decisions made by young women who are aware of other available options. The readers of Junk and Game Girls do not need to align themselves with innocent characters; indeed, these novels seem intended to appeal to sexually knowing teens who are curious about prostitution. However, they also function as warnings to readers who think that they know enough to dabble in the sex industry.

\section{Shameless Sluts: Voluntary Prostitution and the Wages of Sin}

The earlier of the two novels depicting voluntary prostitution, Melvin Burgess's Junk, caused huge controversy in the newspapers when it was first published (Rudd). Nevertheless, it received several major literary awards, including the Carnegie Medal and the Guardian Children's Fiction Award, for its presentation of teenage runaways who live in squats and become addicted to heroin. Burgess is one of the writers to whom Reynolds accords an active role in changing the culture of children's literature and attitudes toward adolescent sexuality in a "radical" direction (114ff). When writers like Burgess and Waite acknowledge that teenagers already know about the sex industry, and may even have considered working as prostitutes or "going VIP" (agreeing to have sex in return for an evening of being pampered with champagne, limousines, etc.), they offer a radically different view of adolescent knowledge from that presented by those authors discussed by Trites. Yet although both Waite and Burgess are very liberal, even celebratory, about teenagers voluntarily having sex with one another, they are also keen to confront their readers with how little they really know about the potential damage sex can cause.

Burgess's novel starts with a young teenage couple spending the night in the back of a Volvo. The boy, Tar, is covered in bruises from his father's latest beating. He has decided to run away from home and asks his fourteen-year-old girlfriend, Gemma, to join him. Gemma's response- "You must be crazy ... What have I got to run away from?" (1) —is supported by all that readers see of her family life. Gemma's parents are neither abusive nor neglectful. Their determination to curb their unruly daughter's behavior is expressed through shouting and limiting her freedoms, but does not extend beyond what are commonly perceived to be acceptable limits of concerned-even anxiousparenthood. The trouble is simply that Gemma is bored: "Gemma was the most bored person she knew. Sitting in class she sometimes felt dizzy with it, that she'd pop or faint or something if it didn't stop. She felt she'd do anything just to have a life" (2). "Having a life," for Gemma at least, apparently involves high risk. She runs away from home just to avoid being bored. Her arrival at the 
squat lifts Tar's spirits, but the sections that are narrated from the perspective of others living in the squat show that they disapprove of her decision to leave a comfortable home, even though they support Tar and his decision to stay away from his abusive father.

Gemma's transition from runaway to prostitute is gradual. While living in the first squat with Tar, she makes the acquaintance of Lily and is immediately drawn to her overt sexuality and charismatic extroversion. Gemma copies everything Lily does; as a result, she soon becomes addicted to heroin. Raising the money needed to score "junk" becomes an urgent problem in a section of the novel narrated by Gemma. The teenagers are suffering from acute withdrawal symptoms after an extended heroin binge. The previous chapters have revealed that they are no longer capable of motivating themselves to do anything other than feed their habit, and that heroin has numbed all their senses, including their desire for sex. Lily is suffering the worst, and in the afternoon she disappears for a while, returning with "free money" (157) from having been "a little prossie for half an hour" (159). Since the section is narrated by Gemma, who idolizes Lily, there is no disapproval. On the contrary, Gemma admires Lily for her resourcefulness, her generosity (she shares the heroin purchased with the money she has earned), and her bravery. And Lily admits that she gets a thrill from the risk surrounding the selling of sex (158). From this point onward, prostitution becomes the main form of income for the girls in the squat. The teenagers' world mimics the gender order of street prostitution: the boys also cottage themselves in men's toilets (255), but their main sources of income come from pimping the girls, selling stolen goods, and dealing. The window in which prostitution is a genuine choice is very small; having entered the sex industry, the girls are no longer able to make choices. The overwhelming need for heroin to feed their addiction is the motivating force, but having discovered that the sex industry is the only way to finance those cravings, they are forced to operate within strictly defined limits. The novel thus highlights the economic aspect of prostitution, but by showing how the teens lose all desire for sex with their established partners, Burgess also triggers warnings about the impact of prostitution on the teens' capacity for jouissance.

Burgess undermines the notion of free will in the context of prostitution, as well as another popular myth: that prostitutes reduce the incidence of rape. Gemma and her friend Sal convince themselves that their work is an act of "Pervert Prevention" (163). Burgess dismisses this argument by offering a chapter narrated from the perspective of one of their clients: the tobacconist, Skolly. Skolly is offended by Gemma's suggestion that if he didn't visit prostitutes he would be out "molesting little girls" since, in his opinion, his decision to pay for sex with young girls is a morally sound acknowledgment that he is "old and fat and out of breath and if I want anyone to sleep with me I have to pay for it" (203). The novel merely presents these two viewpoints and leaves readers to judge for themselves. This trusting relationship with the readers, David Rudd argues, "has a brutal honesty with its disavowal of the usual adult know-it-all 
voice" (121). The respect Burgess shows for his young readers, according to Rudd, makes the didacticism of the novel's antidrug message more palatable and thus more effective. Yet for all its seeming willingness to leave the decision making to the young readers who hear the many different characters' opinions and motivations, Junk is not shy about warning readers of the dangers of the "free money" that can be earned from prostitution. The crisis that breaks up the squat and drives Gemma back to her parental home comes when Lily is badly beaten by one of her clients; Gemma realizes that Lily is placing her life at risk, and calls the police.

The contrast Burgess makes between Lily and Gemma is in terms of levels of risk. Lily is the bad influence who encourages Gemma to make decisions that leave her vulnerable. First Lily persuades Gemma to move out of the relatively safe squat into a higher-risk shelter, then to take heroin, and finally to take up prostitution. Both become pregnant. Lily's behavior is consistently more extreme than that of Gemma, and this dynamic also extends to the way the two girls work within the sex industry. Gemma and Sal work in a massage parlor and feel safe, as the pimps are there to take care of difficult clients. Lily, on the other hand, continues to prostitute herself on the street. In this respect, Burgess promotes the view that some forms of prostitution (escorts, massage parlors, etc.) are safer than others (e.g., street walking); indoor spaces are presumed to be safer than outdoors. ${ }^{6}$ Unlike his questioning of the myth of "pervert prevention," Burgess seems to be promoting a fairly stereotypical view of prostitution, but at least he does not resort to the simplistic "innocent victim versus bad woman" binarism.

Judy Waite's novel Game Girls also resists the idea that those who choose prostitution are simply bad women. For Alix, Courtney, and Fern, prostitution seems to be even more of a choice than it is for the characters in Junk. Gemma's initial motivation for leaving home is boredom, but her decision to prostitute herself arises as a means of satisfying her heroin addiction. For the characters in Game Girls, the motivation seems trivial; on the surface, all three girls just seem to want to earn money to buy luxuries like expensive clothes, shoes, and holidays (and readers may well relate to the allure of consumerism). They appear to have no real need to sell themselves, but the novel attempts to explain their behavior by providing insights into their deep-seated fears, even though they discuss only the financial aspects among themselves. They believe that they know enough about how the sex industry works to be able to benefit from it, but these beliefs are undermined during the course of the novel as the girls, along with the reader, are forced to connect prostitution with violence and exploitation.

Fern, Alix, and Courtney are in their final year at school when they start earning money through prostitution. The idea is sparked when the sexually naive, lonely Fern goes on a blind date with an older man called Steve whom she has met through the Internet. Steve pushes Fern into giving him a "hand job" and then, when he realizes how young she is, panics, thrusts $\mathfrak{£} 50$ into her hand 
and leaves (11-13). Fern uses the money to buy a designer dress in a sale for Alix, whom she admires. Alix wears the dress at her eighteenth birthday party, where she drinks too much and ends up being forced to have sex with two of her brother's friends at the same time. The novel thus begins with a fast-paced reiteration of the pattern established by Trites in Disturbing the Universe, in which teenagers who do not curb their sexuality are punished: "the character's sexuality provides him or her with a locus of power. That power needs to be controlled before the narrative can achieve resolution" (85). Fern is punished for responding to Internet advertisements, and Alix for dressing provocatively and drinking alcohol. Although the acts themselves might not have appeared in young adult literature of the 1980s, the overtly wagging finger of the adult author is certainly consistent with the genre; this cautionary subtext becomes evident in the immediate distress both girls feel when their sexuality leads them into abusive situations.

The "radical" movement Reynolds identifies is evident in how the girls respond to their situation. Instead of regretting the error of their ways and showing signs of becoming socialized into adopting adult-sanctioned behavior (the pattern identified by Trites), the girls believe that despite their recent experiences of sexual abuse, they know enough about sex to be able to use it for their own gain —an idea that Alix, at least, finds empowering. This set-up enables Waite to become quite remarkably didactic, as the girls suffer far worse fates than anything offered in the books Trites analyzes.

Alix wakes up the morning after her eighteenth birthday party hung over and full of shame and remorse, but with no sense of being violated; she does not seem to categorize the sex she has had with her brother's friends as date rape. The novel never characterizes the event as anything other than the consequences of dressing too provocatively and drinking too much. Indeed, Alix's response is to assume that she was solely responsible (and thus solely to blame) for her sexual acts, and the novel does not critique this view. The idea that girls are exclusively responsible for placing limits on their bodies is hardly original in either public discourse or adolescent fiction. What is unusual is Alix's response to the situation; she does not regard herself as a victim, but as a "slut." She accepts the label, but attempts to shift the power balance and use it to her advantage. When she tells Courtney and Fern about her plan, she explains, "Sex. For money. I don't see anything terrible about it. It's no worse than just going with someone-some stranger-for one night. In fact, it's better. At least you'd be in control" (101). Alix's feeling that she is "in control" is foregrounded when she negotiates with the two men with whom she had involuntary sex on her birthday, and they become the brothel's first paying clients.

The girls assume that their knowledge about sex will give them agency, but Waite is at pains to point out how little they, and perhaps the reader, really know. Unlike the two narratives on forced prostitution discussed above, Waite confronts readers with graphic information about sexual violence. By focalizing 
her novel through three characters with decidedly different personalities, she can maximize the chances of engaging the reader's empathy. Each girl then suffers as a consequence of her decision to enter the sex industry. Importantly, the nature of their suffering is directly connected to the level of their sexual knowingness prior to prostitution. Unlike Sold and "Charlotte," Game Girls presents sexual ignorance as a problem; the less these characters know, the more they suffer.

Alix, the most sexually confident of the three, is in charge. Since her mother lives abroad with her latest boyfriend, Alix lives alone and can use her mother's house as the girls' base. She immediately invites Courtney to join her in her plan to establish a brothel in her home; Alix recognizes that Courtney is both sexually knowledgeable and in need of money. What Alix does not realize is that Courtney needs money to escape her own home, where she has been sexually abused by her father. In other words, Courtney knows a great deal about sex-more than Alix does-but her sexual history consists solely of involuntary acts. Fern, a virgin, joins in, not for the money per se, but because she longs to be accepted as part of the group. The novel emphasizes her loneliness as a way of explaining why she is so willing to copy the other girls. Initially, she only offers nonpenetrative sex, but is soon persuaded by Alix and Courtney to go further and thus loses her virginity to a violent client.

Fern's story provides the traditionally moralizing narrative associated with the depiction of adolescent sexuality in teenage fiction as identified by Trites. Fern behaves naively during her blind date with Steve and is willing to prostitute herself to alleviate her loneliness. As a result, she is punished by the violent loss of her virginity, and eventually she is so badly beaten by a client that Alix drowns her rather than taking her to the hospital and exposing the existence of the brothel. Fern's total lack of knowledge-she is a virgin and, like many of Waite's readers, only knows in theory "who does what to whom and how" (Reynolds 117) — places her at risk. Waite is decidedly not promoting ignorance as a virtue; on the contrary, the fact that Fern's punishment is the most extreme is a warning to young readers that "innocence" (defined here as sexual ignorance) will not protect them. Fern's ignorance, in combination with her extreme loneliness, makes her vulnerable. Alix is able to manipulate her into accepting more clients than either she or Courtney take on; she does not attend the health checks with the others; and, on her last night, Fern is so caught up in Alix's idea that the clients think she is beautiful and sexy that she overlooks the warning signs of her client's violent intentions. He whispers in her ear; she assumes he is whispering sweet nothings, and does not listen to his stream of abuse until he has her in his grip and is shouting at her (308-10).

Alix and Courtney's stories, however, seem to offer a far more radical vision of what is possible in an adolescent novel, and do suggest a more complex change in attitudes toward teenagers' perceived sexual knowledge. Knowledge is power, and both are knowing teens determined to use their sexuality in order to gain economic independence. They initially feel empowered by their ability to earn money from prostituting themselves, in no small part because 
they both have been sexually abused. After Alix has serviced her first paying clients, she is described as "glowing"; receiving payment in return for sex feels empowering and resolves her earlier feelings of shame (132).

But even though Alix appears knowledgeable, and has been abused when drunk, she lacks knowledge of sexual violence. This is revealed during an encounter with a client who is a doctor in a downtown area of New York City. During a holiday abroad, Alix arranges to have sex with "a bearded American" for money rather than a gorgeous man her own age, because "She has stopped feeling anything for guys. She gazes back at them, and works out how much they might be prepared to pay" (182). The doctor frightens Alix by pointing out the range of risks she has been taking while believing she was in control. These extend beyond the use of condoms to the risks posed by her earrings, necklace, and bathrobe belt as potential weapons; the location of her keys and the possibility her drink was spiked are mentioned as ways clients might be able to overpower her when she is not expecting it. Each risk is a shock to Alix, and is presumably also to readers as they realize how little they really know. This new knowledge encourages Alix to take more precautions, such as installing a panic button in each room in the brothel, but she is determined to continue. Readers are now better equipped to assess how risky the girls' behavior is and to feel anxious for them. Those who condoned their actions earlier are no longer allowed to feel so confident in the girls' ability to deal with difficult clients. The confrontational style of the doctor's lecture encourages readers to feel ignorant for not recognizing the risks sooner.

Courtney has much more experience of sexual violence than Alix does. Her story introduces a common explanation offered by real prostitutes who "decide" to enter the sex industry: "women who appear to choose prostitution have been sexually abused as children at much higher rates than other women" (Farley 111). For Courtney, the money she earns from prostitution offers a means of escape from her father's house. But she is clearly traumatized by her first experience of paid sex; she showers for ages and then heads for a park where she used to go as a young child. There she encounters a mother and child feeding the ducks, and it is clear that Courtney loathes herself, and considers herself someone to be avoided. By the fifth client, she is able to dissociate, watching the curtains and performing random mathematics in order to keep her mind off what she is doing. This dissociation and self-loathing become integrated into Courtney's sense of self, and the novel stresses that her short-term empowerment gained from earning money is no compensation for her loss of personal integrity. This is clarified when Courtney is raped by her boss at her day job; he assumes that because she is a prostitute, he can take what he wants for free and by force. Prostitution is only empowering for Courtney because it provides her with the finances she needs to leave her parental home.

Courtney's story ends on a surprisingly positive note, after she falls in love with Elroy and has sex voluntarily for the first time. She has never known pleasurable sex, and this knowledge is truly empowering. Afterwards, she admits 
to her mother that she has been abused by her father. Her mother accepts her word, throws her husband out, and arranges therapeutic support for all the family, herself and her sons included. This, in our view, makes Game Girls the most radical of the four narratives. For Courtney, freely expressed sexual desire is a positive life force which enables her to take her life into her own hands and begin the process of healing. Not even Burgess, who has a reputation for being very positive about adolescent desire, is as enthusiastic about the creative potential of consensual sex. Where the other three narratives foreground the sexual dangers intrinsic in prostitution, Waite foregrounds motivation. She condones sex for pleasure but warns adolescents of the dangers inherent in having sex for profit, to alleviate loneliness, or to escape another situation.

Both Junk and Game Girls attempt to provide credible reasons why girls from seemingly comfortable homes might turn to prostitution. One of the most important things both these and the narratives on clearly forced prostitution accomplish in political terms is to make prostitution visible. As Farley points out, there is a "connection between not seeing prostitution and keeping it in existence" (109). These novels, which present prostitution as a choice, challenge the view that it is something that happens to other people, a view that dominates presentations of victims of sex trafficking. However, they are very clear that there is only a very small window in which true choice is possible; having entered the sex industry, the characters are all overtaken by its momentum. These novels present third-millennium teenage girls as people who know something about sex, and who may even be sexually experienced. But their authors are keen to expose gaps in the teenage characters' knowledge, and so warn young readers that they may be harmed if they make unwise choices about their sexual bodies. Both novels deconstruct the concept of voluntary prostitution; their readers are assumed to believe that prostitution can remain a voluntary act, and the narratives challenge that view. Part of the new knowledge Burgess and Waite attempt to impart is that volition is easily curtailed.

In both novels, explicit, onstage sexual acts are limited to acts of violence. Gemma and Tar's mutual loss of virginity and Courtney and Elroy's gentle lovemaking are referred to but not narrated. These are private acts. Even the nonviolent sexual encounters with clients are not fully narrated; the girls in Game Girls tend to dissociate, and as a result at key moments the narrative follows their train of thought as they watch the curtains, think about their pottery, or plan a holiday. The novels thus protect their young readers from witnessing the detail of "who does what to whom and how" (Reynolds 117). What they will learn from these books is not what to do, but how to reassess what they think they know. Even Courtney, with her extensive sexual knowledge gained from encounters with her father, her clients, and her boss, knows nothing about the healing potential of sex. And none of the girls in Junk or Game Girls realizes the full danger of prostitution, despite their varied sexual knowledge prior to their entering into the sex industry. The girls may have chosen to prostitute themselves, but neither novel presents a rosy picture of the consequences of 
those decisions. Burgess's and Waite's didacticism is all the more effective because it manages to connect the selling of sex with violence without appearing to lecture at their young readers.

\section{"Knowing" about Sex in the Third Millennium}

Where writers in the 1970s shocked the general public by acknowledging that teenagers already knew quite a bit about sex (and wanted to know more), writers at the cusp of the third millennium assume their readers already know "who does what to whom and how" (Reynolds 117), and that sex can be treated as a commodity. However, because texts assume that young readers are knowledgeable about the mechanics of sex, young people are assumed to be at even greater risk than their counterparts four decades ago because they do not know that they lack knowledge. All four authors encourage their young readers to reassess what they think they know and to identify gaps in their knowledge. More specifically, the texts emphasize the connection between the commodification of sexuality and violence. Readers are also encouraged to distance themselves from the experiences of the teenage characters, but not to judge them harshly. Indeed, all four narratives encourage readers to feel pity rather than disdain.

The two narratives on forced prostitution are committed to human rights education, but rely heavily on the assumption that some prostitutes are "innocent" (and, by implication, that others are not). They encourage young readers to feel pity and be sympathetic toward prostitutes as a vulnerable group of people, but not to think that Lakshmi and Charlotte are "like me." Both narratives assume no prior knowledge of how poverty and social conditions may factor into prostitution; indeed, they do not assume that their readers have ever even thought about prostitutes at all. In contrast, both Burgess and Waite appear to write for an audience that has thought about prostitution and is presumed to know how the sex industry works. They fill gaps in their readers' knowledge by stressing the heavy toll of prostitution on the individual's psyche, the extreme violence sex workers commonly face, and the limitations on possibilities for choice. Having decided to sell sex once, characters are overtaken by the machinery of the sex industry and cannot find a way out. In filling in these perceived gaps in their readers' knowledge, the four texts reveal a candor and respectful willingness to communicate, even though they clearly wish to deter their audience from emulating their characters' behavior.

Recalling Reynolds's finding that "children's literature participates in shaping-it does not merely reflect-changing attitudes to young people" (115), one can consider the impact of books depicting teenage prostitutes. For the most part, the underlying trends seem little changed; all four authors warn their readers that sex is a powerful force that has the potential to unleash great harm, as sex and violence are intimately linked. Sadly, the narratives are much more cagey about the positive potential of sexual desire. Elroy's respectful lovemaking is what Courtney needs in order to begin the process of healing from the abuse 
she has received at the hands of her father and the men who visit the brothel. Waite's depiction of adolescent desire as a source of healing is more unusual than her heavy-handed yoking of sex and violence in the brothel, but this is unlikely to remain uppermost in readers' memories. The novel's association of sexual knowledge with violence and the loss of agency overshadows Courtney's healing. The same is true of the narratives by McCormick, Burgess, and Hooper. Readers are left with new information about the violence to which prostitutes are subject.

The third-millennium child is a knowing child. Although literature can never and has no need to replace the kinesthetic knowledge gained from actual experience (Grosz 286), it continues to offer greater potential than does formal sex education for communicating across the generational divide about the emotional impact of sexual relationships. Consensus on precisely what adults think teenagers should know about sex may never be reached, but these narratives indicate that a shift is taking place in terms of both what teenagers need to know and what they are expected to know. They are certainly not expected to be ignorant, but there are clear signals that third-millennium authors do not consider their knowing teenage readers to be particularly knowledgeable about the sex industry.

\section{Notes}

1. See Bruhm and Hurley for a discussion of how innocence and the assumption of heterosexuality intertwine in an Anglophone context; Franck addresses this topic in a Swedish context.

2. In Fictions of Adolescent Carnality, Kokkola discusses the presentation of adolescent sexuality as a problem that needs to be solved in teenage fiction as part of a larger project of constructing adolescence as a period of sturm und drang. Her study of a corpus of two hundred narratives intended for teen readers (including the four discussed here) reveals a remarkably consistent image of the troubled teen lying beneath works that on the surface, at least, seem very different.

3. The novels are not intended for teenagers who actually work in the sex industry; the texts position their readers as lacking knowledge about how prostitution impacts upon the individual's psyche.

4. See Farley for a discussion of the "cultural amnesia" surrounding prostitution, trafficking, and the sex industry.

5. See, for example, Higonnet for a discussion of images of sexual innocence; Kincaid's Child-Loving and Erotic Innocence on how the media promote sexual innocence as an ideal, and its consequences; and Natov regarding how the presumed sexual innocence of the child is manifested in children's literature.

6. In an article summarizing research in the area of prostitution and the well-being of prostitutes, Farley cites evidence showing similar levels of rape for both so-called high-class call-girls and street prostitutes (120-21). She also demonstrates that the 
circumstances under which prostitutes work "meet or exceed legal definitions of torture" (122; emphasis original).

\section{Works Cited}

Burgess, Melvin. Junk. 1996. London: Penguin, 1997.

Bruhm, Steven, and Natasha Hurley, eds. Curiouser: On the Queerness of Children. Minneapolis: Minnesota UP, 2004.

Dearth, Paige. Believe Like a Child. Lavergne, TN: CreateSpace, 2011.

Doezema, Jo. "Loose Women or Lost Women? The re-emergence of the myth of white slavery in contemporary discourses of trafficking in women." Gender Issues (Winter 2000): 23-50.

Duncan, Simon. "What's the Problem with Teenage Parents? And What's the Problem with Policy?" Critical Social Policy 27.3 (2007): 307-34.

Emge, Diane. "I'm Pregnant!: Fear and Conception in Four Decades of Young Adult Literature." Young Adult Library Services 4.2 (2006): 22-27.

Farley, Melissa. "Prostitution, Trafficking, and Cultural Amnesia: What we must not know in order to keep the business of sexual exploitation running smoothly." Yale Journal of Law and Feminism 18 (2006): 108-44.

Forster, E. M. Aspects of the Novel. 1927. London: Penguin, 2005.

Franck, Mia. Frigjord Oskuld: Heterosexuellt mognatsimperativ i svensk ungdomsroman [Empowered Innocence: Heterosexual developmental imperative in Swedish young adult fiction]. Turku: Åbo Akademi UP, 2009.

Grosz, Elizabeth. Space, Time and Perversion. New York: Routledge, 1995.

Higonnet, Anne. Pictures of Innocence: The History and Crisis of Ideal Childhood. London: Thames and Hudson Ltd., 1998.

Hooper, Mary. “Charlotte.” Losing It. Ed. Keith Gray. London: Anderson P Ltd., 2010. 119-44.

Jeffries, Susan. The Idea of Prostitution. Melbourne: Spinifez P, 1997.

Kincaid, James R. Child-Loving: The Erotic Child and Victorian Culture. New York: Routledge, 1992.

. Erotic Innocence: The Culture of Child Molesting. Durham, NC: Duke UP, 1998.

Kokkola, Lydia. Fictions of Adolescent Carnality. Amsterdam: John Benjamins. 2013.

. "Metamorphosis in Two Novels by Melvin Burgess: Denying and Disguising

'Deviant' Desire." Children's Literature in Education 41.1 (2011): 56-69.

Levine, Judith. Harmful to Minors: The Perils of Protecting Children from Sex. 2002. New

York: Da Capo P, 2003.

McCormick, Patricia. Sold. London: Walker Books Ltd., 2008.

Natov, Roni. The Poetics of Childhood. New York: Routledge, 2003.

Reynolds, Kimberley. Radical Children's Literature: Future Visions and Aesthetic

Transformations in Juvenile Fiction. Houndmills, UK: Palgrave Macmillan, 2007. 
Ringdal, Nils Johan. Love for Sale: A World History of Prostitution. 1997. Trans. Richard Daly. New York: Grove P, 2005.

Rose, Jacqueline. The Case of Peter Pan, or The Impossibility of Children's Fiction. 2nd ed. London: Macmillan, 1992.

Rudd, David. "A Young Person's Guide to the Fictions of Junk." Children's Literature in Education 30.2 (1999): 119-26.

Sanders, Teela, Maggie O’Neill, and Jane Pitcher. Prostitution: Sex Work, Policy \& Politics. London: Sage Publications, 2009.

Thiel, Elizabeth. The Fantasy of Family: Nineteenth-Century Children's Literature and the Myth of the Domestic Ideal. New York: Routledge, 2008.

Trites, Roberta Seelinger. Disturbing the Universe: Power and Repression in Adolescent Literature. Iowa City: U of Iowa P, 2000.

Waite, Judy. Game Girls. London: Anderson P Ltd., 2007. 